\title{
A conversation with Bill Paul
}

No

oted immunologist, William (Bill) Paul, NIH distinguished investigator and chief of the Laboratory of Immunology within the National Institute of Allergy and Infectious Diseases (NIAID), is best known for the discovery of the cytokine interleukin-4 (IL-4), and the description of its receptor and characterization of its associated signaling mechanisms. Paul (Figure 1) is also an important contributor to understanding $\mathrm{CD}^{+}{ }^{+} \mathrm{T}$ cell differentiation, lymphocyte dynamics, and B cell biology. The full interview with a man described as the consummate physician-scientist and a terrific mentor is available on the JCI website (https://www.jci.org/videos/cgms).

JCI: Where did you grow up?

Paul: I was born in Brooklyn. My father had a small automobile repair business. We lived in Brooklyn until almost the time I finished high school, when we moved to Queens. But I came back to Brooklyn for college at Brooklyn College, where I became very interested in science.

As is not unusual in oldest boys in Jewish families, the notion of being a doctor was very prominent in my parents' minds. Being a relatively dutiful son, I pursued that but always wanted to make a small contribution to science. I went to medical school, also in Brooklyn, at Downstate Medical Center. It was a good experience, and I worked summers in a lab with a very nice man, George Talbert, who was interested in pituitary hormones. We didn't do anything shockingly new, but it was a really great experience.

JCI: During your residency, you did work on the structural components of amyloid fibrils.

Paul: I was a good student but wasn't a fantastic doctor. Being a physician combines deep scientific knowledge with an ability to perceive a patient in a unique way. I wish I could say I had that gift, but I don't believe I did. I worked dreadfully hard at being a house officer.

I did my internship and assistant residency at Massachusetts Memorial Hospital. They had a nice program that allowed a month off during your assistant residency, when you could do research. I met a new recruit, Alan Cohen, who was an expert in amyloidosis. Alan needed people and was willing to tolerate an unskilled, but enthusiastic, assistant resident.

What we did would seem simple today, but the question was, to what extent were amyloid fibrils composed of immuno-

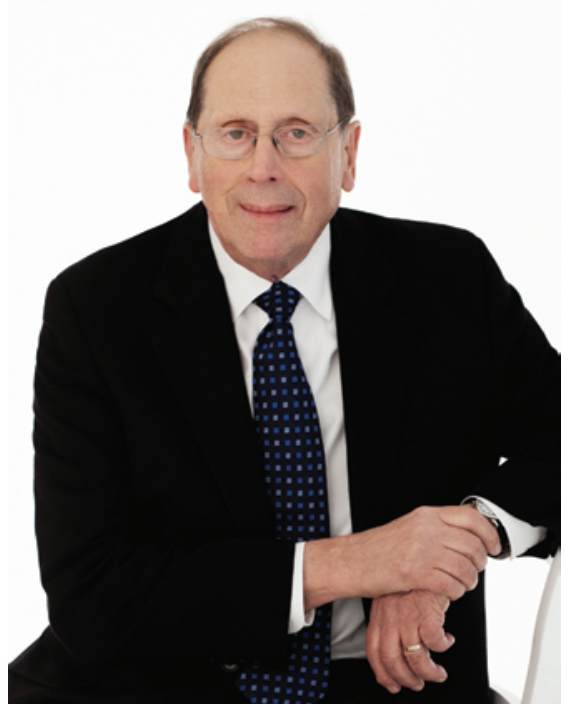

Figure 1. Bill Paul on February 24, 2015. Image credit: Alena Soboleva.

globulins or antibodies? We used a recent advance in electron microscopy, in which you could tag antibodies with ferritin to make them visible.

At the end of residency, I applied to the NIH to join the Public Health Service to both fulfill my military obligation and have the opportunity to work in what was the most remarkable place to do both basic and clinical science.

JCI: At the NIH, you started working on metastatic choriocarcinoma.

Paul: A protein hormone group in the NCI, headed by Roy Hertz, chose me, for which I was enormously grateful. Roy was very interested in choriocarcinoma, which is a malignancy of the trophoblast. $\mathrm{He}$ devised the treatment of this metastatic disease with methotrexate. Remarkably, most of the patients who came to the
NIH would have metastatic disease - if you looked at their chest X-rays, they would have infiltrations the size of grapefruits. Once treated with methotrexate, in most of them, the tumors would regress and disappear. These were true cures. Many of these women went on to have subsequent children. You could not have asked for a more fulfilling opportunity as a clinician scientist.

JCI: And yet it did not motivate you to stay in the field?

Paul: When I was either in college or medical school, I came into possession of a slender volume of essays by a man named Michael Heidelberger, who was responsible for the development of quantitative methods to study antibody-antigen interaction. He put immunology, in a sense, on a scientific footing. He wrote so vividly about the remarkable capacity of antibodies to bind antigens that I was just completely taken.

Together with my work with Alan, it made me feel I wanted to do immunology. Even though I was in a protein-hormone group, the research was centered on the immunological properties of protein hormones; in addition to the choriocarcinoma work, we developed a radioimmunoassay for thyroid-stimulating hormone.

Nonetheless, I wasn't in the mainstream of immunology. Based on counsel received from notable immunologists Byron Waksman and Sid Leskowitz, I was told that the two most exciting immunology labs were Baruj Benacerraf at NYU and Henry Kunkel at the Rockefeller. Based on their advice, I applied to both labs.

Henry was very cordial but explained that his laboratory was full. If I wanted to apply to the graduate school to get a $\mathrm{PhD}$, he said he could squeeze me in. By then, I was out of medical school for several years. Marilyn and I had a son. I was reluctant to consider undertaking a $\mathrm{PhD}$.

Kunkel was the true establishment figure. Benacerraf, by contrast, was a brash young man on the way up, although, looking at him, you would not have reached that conclusion. He was short and somewhat overweight, spoke with a high-pitched voice - but that belied a tower of strength.

Baruj interviewed me, and he sent me around to all his colleagues. And at the end 
of the day, we talked and he said he would think about it. Two weeks later, a letter arrived saying that I could join his group. However, he said I should know that he was going to take a sabbatical next year. Benacerraf never took the sabbatical, and I arrived in his lab on July 1, 1964.

JCI: So what did you focus on when you were in the Benacerraf lab?

Paul: We already knew there were different kinds of immunity: humoral (based on antibodies) and cellular immunity. But the distinction between $\mathrm{T}$ and $\mathrm{B}$ cells had not yet been made. What Baruj proposed I do was to try to understand a phenomenon called "carrier specificity." In immunology, small molecules (haptens), by themselves, don't elicit immune responses. But if they're conjugated or chemically coupled to an immunogenic protein, then antibody will be produced that reacts with the small molecule. So there is a distinction in the concepts of the ability to induce an immune response (immunogenicity) and the ability to be the target of antibodies (antigenicity).

The question was, what was the carrier specificity of the anti-hapten antibodies? And how did it compare with the carrier-specificity contribution of cellular immunity? The notion would be we've immunized an animal with a conjugate of a nitrophenyl ring conjugated to a protein or a polyamino acid. We would elicit immune responses. We'd purify antibodies on the one hand or cells on the other. We would confront the cells with the hapten on many different carriers and measure their response by determining their proliferation, their uptake of tritiated thymidine. We utilized a powerful technique to measure equilibrium constants, and we could clearly distinguish cellular immunity's specificity from antibody specificity. The cellular response proved to be exquisitely carrier-specific. By contrast, the antibody response was only modestly carrier-specific. I did several other things, but that was the four-year odyssey, and it paid off.

JCI: You moved with him to the NIH.

Paul: NYU was unwilling to make Benacerraf the chair of a Department of Cell Biology and while he was told he should expect to be offered the chair of Pathology at Harvard, the offer did not come. He looked at a lot of other jobs, and one was the head of the Laboratory of Immunology at NIAID. He had discovered what would eventually lead him to become a Nobel Prize winner - the genetic regulation of immune responses - by studying guinea pigs, and the NIH had unlimited numbers of inbred guinea pigs. He accepted the offer and I, being a wonderful bargainer, walked into his office and said, "Baruj, if you take me to NIH, I'll be delighted to go with you.'"

JCI: Once there, how did you set yourself apart from your mentor?

Paul: We made an arrangement that I would work in collaboration with him $50 \%$ of my time, and $50 \%$ of my time, I could work on whatever I liked. I was "saved," as the position at Harvard that he was told to expect was indeed offered about a year later than he expected. He stayed just another year in Bethesda.

There was a hoo-ha about who would replace him. The NIH became a little desperate, and somehow I was offered the job. At 34 , I became a lab chief. And I am not absolutely certain, but I suspect I was the youngest lab chief on the campus. This was 1970; this year will be my 45 th year as lab chief.

JCI: How did you set about putting your own stamp on the place?

Paul: I was left with this open book, as many staffleft before Baruj got there, fearing his approach. I inherited the good parts of the laboratory. We had great postdocs. I didn't even have to rush because the postdocs were producing marvelous work. I could move ahead with what I call deliberate speed.

JCI: You mentioned these postdocs: you've had the fortune of having some of the best immunological minds pass through your lab, like Charlie Janeway, Laurie Glimcher, Mark Davis. How did you attract them?

Paul: That was serendipity. I do really well with people who are independently minded because I really like the back and forth of a discussion with someone who's willing to speak their minds and will disagree with me.

Mark came with a vision of how he could clone the $\mathrm{T}$ cell receptor, and we got out of the way and let him get on with it. I say one of the great achievements of Laboratory of Immunology, which humbly I believe is my creation, was Mark's achievement of cloning the $\mathrm{T}$ cell receptors. The exciting discovery of IL-4 was also going on in the lab in the same era.

JCI: How did you become the Director of the Office of AIDS Research (OAR)?

Paul: I watched the development of this scourge from the sidelines. There was a lot of skepticism on the part of the advocacy community that the NIH investment in science was paying off. They lobbied Congress for all HIV research resources to be put in a central location. The NIH hated this idea, but Congress passed it and the OAR was born. Harold Varmus had to find an individual to be the director. Most of the big figures in the field felt it would be a political nightmare and stayed out. One person was very interested, Bernard Fields, but unfortunately he had a recurrence of pancreatic cancer while he was negotiating for the job. Harold was ... I won't say desperate, but ... he looked around, and I was the closest person. I used to say to people, "My arm looks perfectly straight now!"

It was a wonderful experience. The activist community was smart as hell, and they understood NIH better than we did. Within a month or two of the time I took over at the OAR, a piece appeared in the CDC's morbidity and mortality report describing how you could reduce the transmission of HIV from mother to child by $90 \%$ or more by treating pregnant women, and then their newborns, with AZT. This was unbelievable and was like a new life for AIDS research. A year or so later, protease inhibitors came online, and now people felt that science really worked. That really gave us an enormous ability to push forward.

JCI: For that role, you were promoted to a two-star admiral.

Paul: Since I'm a retired commissioned officer, I can get my medication at the Navy Hospital across the street, and I have to go through their very modest security, and I have to show my ID. I always get a very nice salute.

JCI: If you couldn't be a scientist or a medical doctor, what vocation do you think you would've chosen?

Paul: It's very hard to say. I was very interested in history and remain so to this day. But whether I would've ever chosen that as a field, I think unlikely. I would say immunology has done something no other field has done: it has eradicated diseases like small pox, rinderpest, and two forms of polio. That's never been achieved, in the history of medicine, by any branch of science other than immunology.

Ushma S. Neill 